Molecules 2000, 5, 1146-1165

molecules

ISSN 1420-3049

http://www.mdpi.org

\title{
A New Pathway to 3-Hetaryl-2-oxo-2H-chromenes: On the Proposed Mechanisms for the Reaction of 3-Carbamoyl-2- iminochromenes with Dinucleophiles
}

\author{
Sergiy M. Kovalenko,* Igor E. Bylov, Konstantyn M. Sytnik, Valentyn P. Chernykh and \\ Yaroslav V. Bilokin \\ Department of Organic Chemistry, Ukrainian National Academy of Pharmacy, Kharkiv 61002, \\ Ukraine.
}

* Author to whom correspondence should be addressed; E-mail: kovalenko_sergey@ukrfa.kharkov.ua Received: 30 July 2000 / Accepted: 19 September 2000 / Published: 31 October 2000

\begin{abstract}
The present account summarizes the author's studies to elucidate the mechanisms of the recently reported rearrangements resulting from inter-and/or intramolecular reactions of 2-imino-2H-chromene-3-carboxamides with different dinucleophiles.
\end{abstract}

Keywords: rearrangements, mechanisms, iminochromenes, nucleophiles.

\section{Introduction}

The coumarin ( $2 \mathrm{H}$-chromen-2-one) moiety is often found in natural products [1]. In view of the ubiquity of this fragment in a variety of biologically active compounds, the synthesis of various $2 H$ chromen-2-one analogs is important in gauging their potential as a source of chemotherapeutics [2]. As part of our investigations on the reactivity of 3-carbamoyl-2-imino- $2 H$-chromenes [3], we recently introduced a new method for synthesis of 3-hetaryl-2-oxo- $2 H$-chromenes [4]. This method was based on the rearrangements of 2-imino- $2 H$-chromene-3-carboxamides into 3-hetaryl-2-oxo- $2 H$-chromenes under the action of dinucleophiles. In this account, results of our studies on clarification of the mechanism of the above-mentioned rearrangements are summarized and exemplified by utilizing anthranilic acid, its derivatives, and arylhydrazides as $N$-nucleophiles. In order to elucidate the

(C) 2000 by MDPI (http://www.mdpi.org). Reproduction is permitted for noncommercial purposes. 
mechanisms of the applied rearrangements, a model system approach based on isolation of stable reaction intermediates or their structural analogs was used.

\section{Results and Discussion}

Several methods for synthesis of quinazolinylcoumarin derivatives of type $\mathbf{7}$ have been reported. For example, compounds of type 7 have been prepared by aminolysis of 4-oxo-2-(2-oxo- $2 H$-chromen3-yl)-4H-3,1-benzoxazines with aqueous ammonia [5], ammonium acetate or formamide [6]. Various

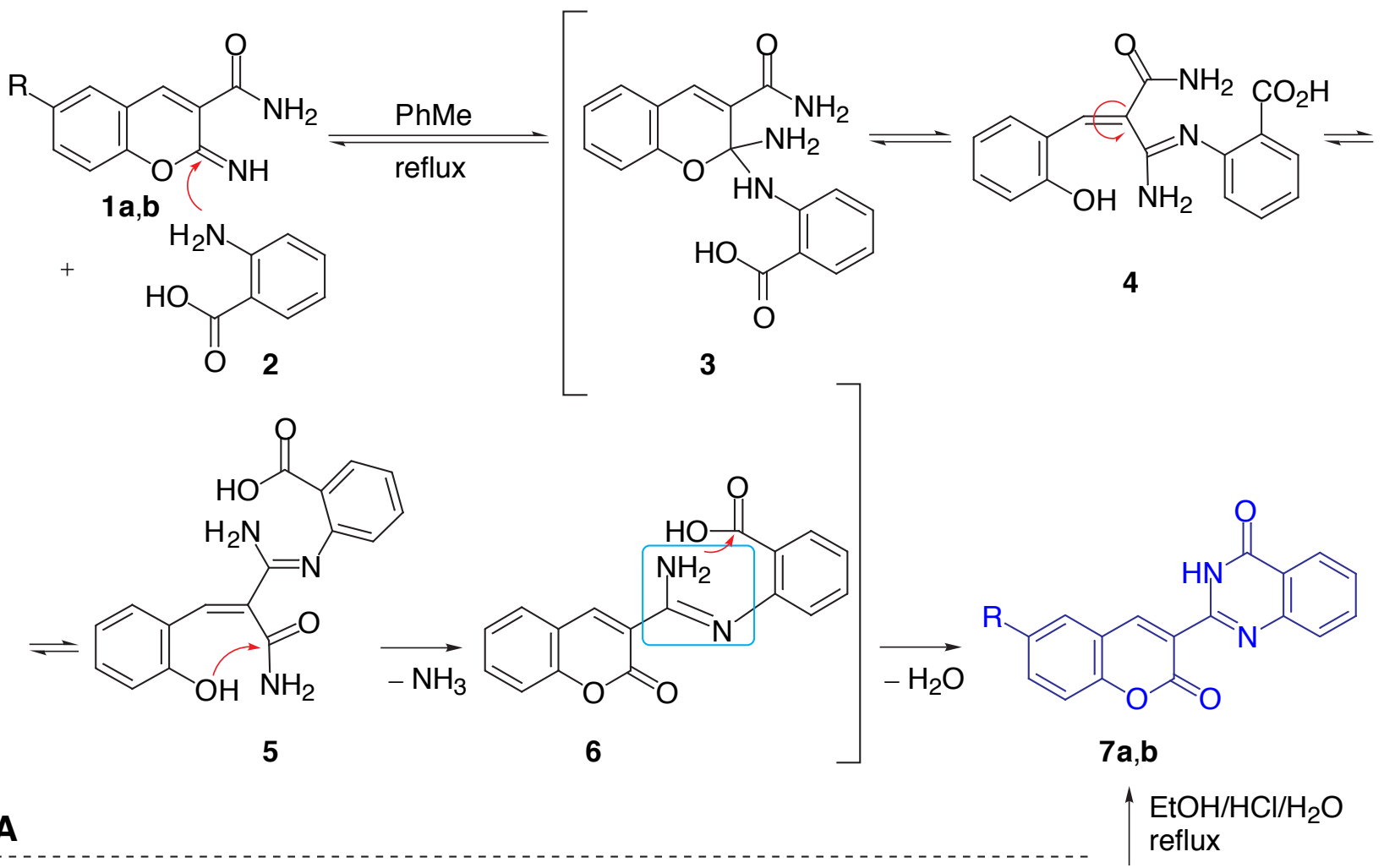<smiles>N#CCc1nc2ccccc2c(=O)[nH]1</smiles>

8<smiles>[R]c1ccc(O)c(C=O)c1</smiles>

9a,b

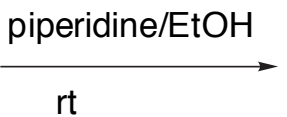

$\mathrm{rt}$<smiles>[R]c1ccc2oc(=N)c(-c3nc4ccccc4c(=O)[nH]3)cc2c1</smiles>

$10 a, b$

B

a: $\mathrm{R}=\mathrm{H}$

b: $\mathrm{R}=\mathrm{OMe}$

Scheme 1. Proposed mechanism for the transformations of 2-imino- $2 H$-chromenes 1 into 3(quinazolin-2-yl)-2H-chromen-2-ones 7 by the action of anthranilic acid (2) under non-acidic conditions 
7-diethylamino-3-(4-oxo-3H-quinazolin-2-yl)-2H-chromen-2-one dyes have been synthesized [7] by the reactions of: (i) ethyl 7-diethylamino-2-oxo-2 $H$-chromene-3-carboxylate with anthranilamides; (ii) cyclization of 4-diethylamino-2-hydroxybenzaldehyde with 2-(cyanomethyl)quinazolin-4(3H)-ones; (iii) 7-amino-2-oxo-2H-chromene-3-carboxamides with isatoic anhydride or of 4-diethylamino-2hydroxybenzaldehyde with acetanilides and subsequent cyclization of the product formed with urethane and phosphorus pentoxide.

Kametani et al. reported [8] the synthesis of 3-substituted quinazolin-4(3H)-ones starting from a sulfinamide anhydride, prepared from anthranilic acid (2) and thionyl chloride, and primary and secondary amides. Our attempts to synthesize quinazolinylcoumarin 7a by simple heating of 2-oxo2H-chromene-3-carboxamide (25 [9], cf. Scheme 9) and anthranilic acid (2) without any additional reagents failed. However, it was found that refluxing of compounds $\mathbf{1 a}, \mathbf{b}$ and $\mathbf{2}$ in degassed toluene afforded compounds 7a,b in moderate yields as the sole products (Scheme 1A). In the course of the reaction, a strong liberation of ammonia was detected. In order to fully characterize compounds $7 \mathbf{a}, \mathbf{b}$, they were also synthesized by an alternative method via Knoevenagel condensation of 2-(cyanomethyl)quinazolin-4(3H)-one 8 [10] with salicylaldehydes $\mathbf{9 a , b}$ in ethanol and using piperidine as a catalyst and subsequent acid hydrolysis of the formed imines $\mathbf{1 0}$ (Scheme 1B).
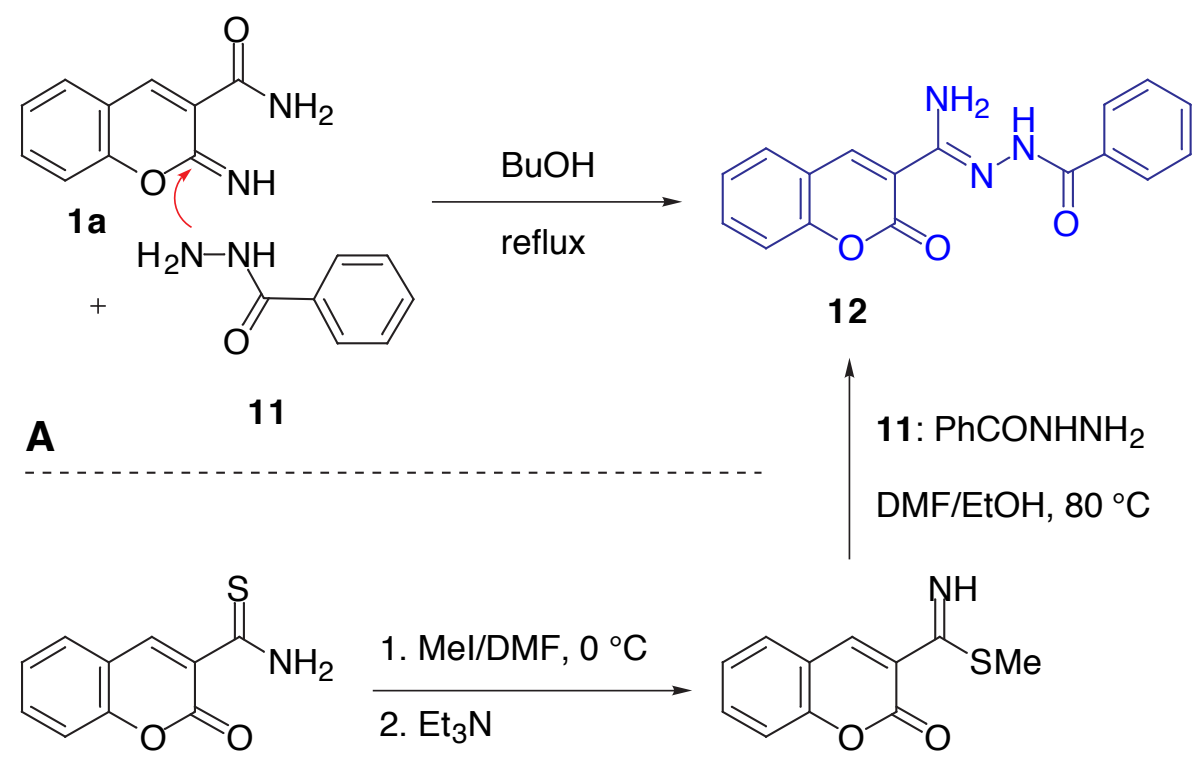

13

14

B

Scheme 2. Synthesis of amide-hydrazone 12 under non-acidic conditions

A mechanism was postulated (Scheme $1 \mathrm{~A}$ ) for the formation of $2 H$-chromen-2-one and quinazolin$4(3 H)$-one moieties via a rearrangement of 2-imino- $2 H$-chromene-3-carboxamides 1 by the action of anthranilic acid (2) as $N$-nucleophile [11] under non-acidic conditions. It may involve several consecutive or concerted steps: (i) intermolecular nucleophilic attack of $\mathrm{NH}_{2}$ on C-2 of the 
iminolactone ring (1+2 53 ), (ii) iminolactone ring opening $(\mathbf{3} \leftrightarrows 4)$ ), (iii) thermal $E / Z$ isomerization [12] of intermediate 4 (4 5 5), iv) cyclization of intermediate 5 to amidine 6; and (v) subsequent formation of $2 \mathrm{H}$-chromen-2-one and pyrimidine fragments $(\mathbf{6} \rightarrow \mathbf{7})$.

To prove the proposed mechanism, we directed our studies to isolation of intermediate amidines of type 6. With this objective in view various heterocyclic systems, not prone to spontaneous cyclization, were designed and synthesized. As an example, refluxing of iminocarboxamide 1a and benzohydrazide (11) (Scheme 2A) in butan-1-ol afforded amide-hydrazone 12, which was also synthesized independently (Scheme 2B) from chromenethiocarboxamide 13 [13] through the intermediacy of carboximidothioate 14. Furthermore, amidines 16a,b were synthesized (Scheme 3) in moderate yields employing the same rearrangement conditions.
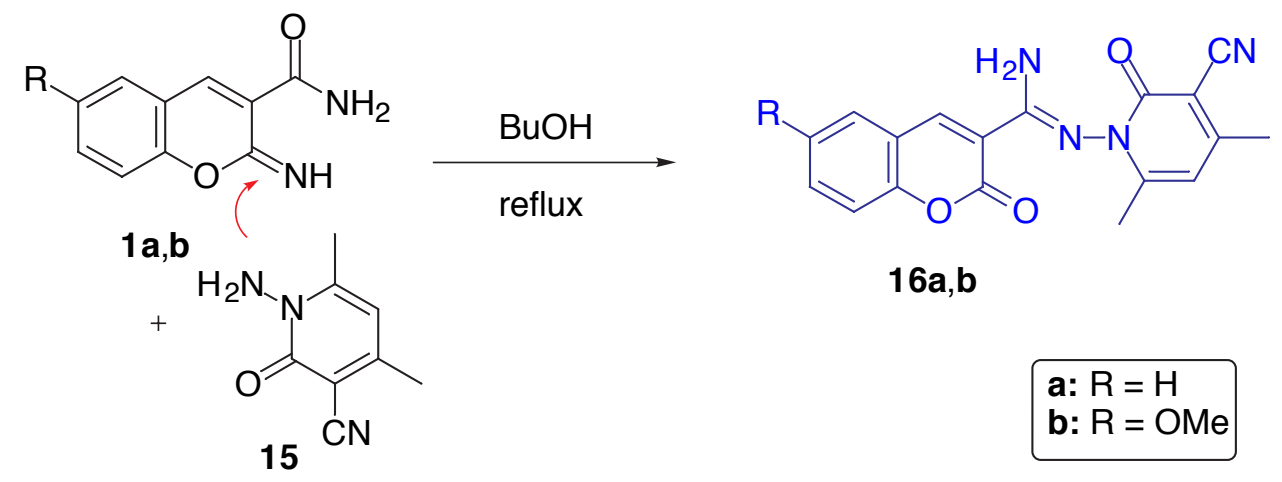

$16 a, b$

Scheme 3. Synthesis of amidines 16 under non-acidic conditions

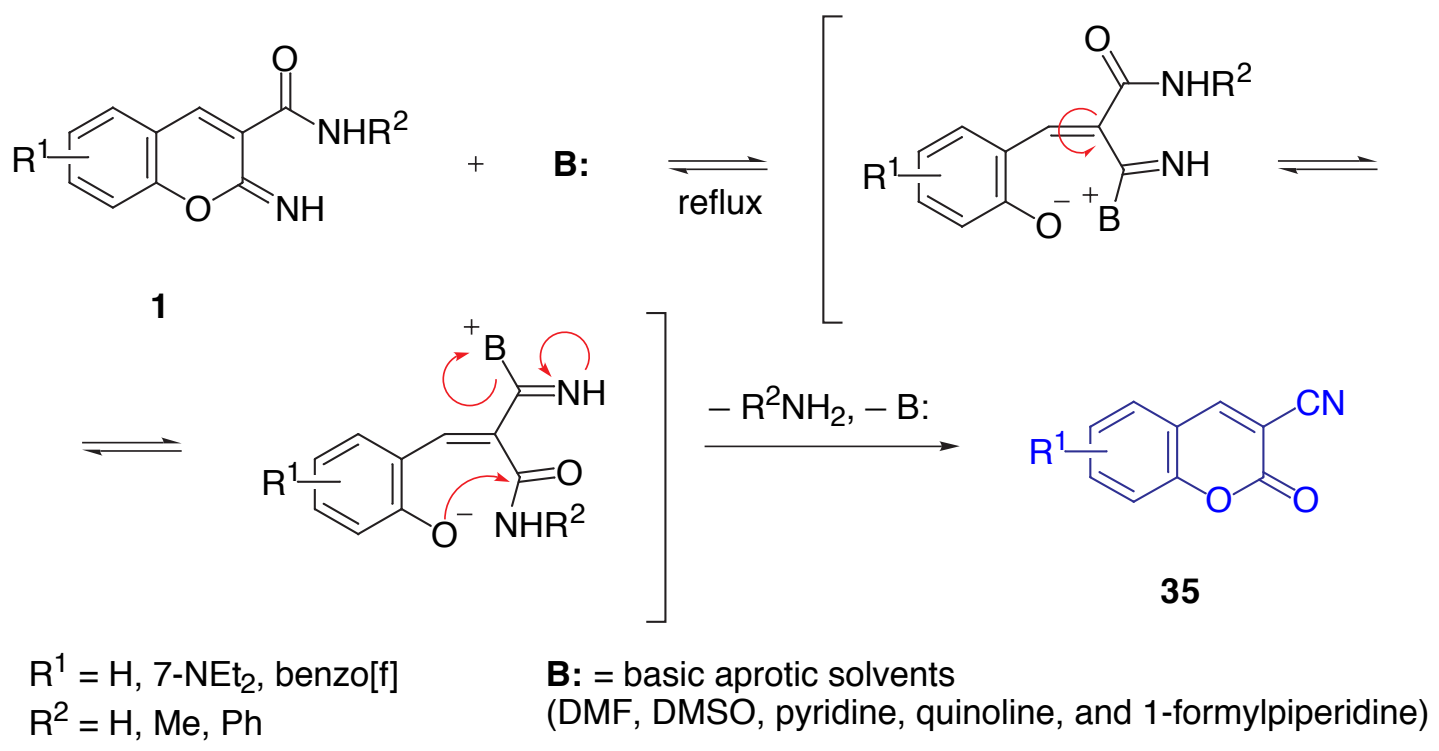

Scheme 4. Proposed mechanism for the transformations of substituted 2 -imino- $2 H$-chromenes 1 in basic aprotic solvents 
It was also shown that 2-imino- $2 \mathrm{H}$-chromene-3-carboxamides of type $\mathbf{1}$ undergo transformation into 2-oxo- $2 \mathrm{H}$-chromene-3-carbonitriles $\mathbf{3 5}$ in basic aprotic solvents: DMF, DMSO, pyridine, quinoline and $\mathrm{N}$-formylpiperidine (Scheme 4) [14]. In contrast, the corresponding 2-oxo- $2 \mathrm{H}$-chromene-3carboxamides 1 did not undergo dehydration to afford 2-oxo- $2 \mathrm{H}$-chromene-3-carbonitriles even after prolonged boiling for 3-4 $\mathrm{h}$ in the above-mentioned solvents. The reaction mechanism of this transformation should be analogous to that presented in Scheme 1A. In this case, solvent acts as a nucleophile and opens the iminolactone ring $(\mathbf{1}+$ base $)$ and then is eliminated with the formation of nitrile group $(\mathbf{1} \rightarrow \mathbf{3 5}$, Scheme 4$)$.

In connection with this, a study on isomerization of chromen-2-imines in DMSO- $d_{6}$ has to be mentioned. O'Callaghan et al. revealed [15] that when unsubstituted 2-imino-2H-chromene-3carboxamide (1a) was dissolved in DMSO- $d_{6}$, the NMR spectra showed that a mixture of both 2 imino- $2 \mathrm{H}$-chromene-3-carboxamide and the isomeric 2-cyano-3-(2-hydroxyphenyl)-prop-2-enamide (Figure 1) was present. Other chromen-2-imines behaved similarly, but the degree of isomerization varied considerably, depending on the nature and position of the substituents.

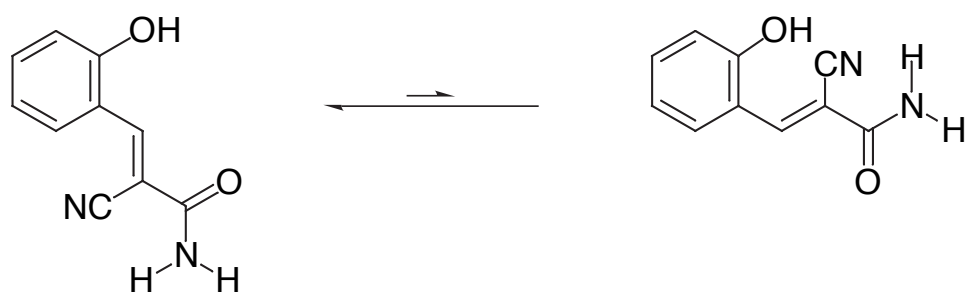

Figure 1.

As shown in Scheme 5 (paths A and B), two distinct pathways leading to different products were envisioned to be involved in the acid-catalyzed rearrangements of 2-imino- $2 H$-chromene-3carboxamides $\mathbf{1}$. Thus, depending on reaction conditions, two types of products might be formed: (i) under non-aqueous acidic conditions compounds, comprising $2 H$-chromen-2-one and quinazoline or benzoxazine moieties $23\left(\mathbf{1} \rightarrow \mathbf{1 9} \rightarrow \mathbf{2 3}\right.$, Scheme 5, path A) or (ii) in aqueous acidic media, where $\mathrm{H}_{2} \mathrm{O}$ acts as $O$-nucleophile, $N$-substituted 2-oxo- $2 H$-chromene-3-carboxamides $28(1 \rightarrow 19 \rightarrow 28$, Scheme 5 , path B). In this case, a competing reaction could be a simple hydrolysis $(\mathbf{1 9} \rightarrow \mathbf{2 5})$, although a full understanding of the factors controlling this competition has not been attained. General intermediates for transformations presented in Scheme 5 are 2-(arylimino)-2 $H$-chromenes of type 19. To verify our assumption of two possible mechanisms of reaction between 2-imino- $2 \mathrm{H}$-chromene-3-carboxamides $\mathbf{1}$ and anthranilates in acidic media, we directed our studies to isolation of intermediate 2-(arylimino)$2 \mathrm{H}$-chromenes 19 and, starting from them, to the synthesis of 3-substituted $2 \mathrm{H}$-chromen-2-ones of type 23 and 28.

A method for synthesis of 2-(arylimino)chromenes 19 was recently introduced in our laboratory and it was shown that a variety of 2-(aryl- or alkylimino)-substituted $2 \mathrm{H}$-chromen-2-ones of type $\mathbf{1 9}$ could be prepared [3]. This method is based on aminolysis of cyclic imido esters and is similar to the 
reaction of simple imidates with amines [16]. This type of reactions should also be similar to the acid hydrolysis of 2-imino- $2 \mathrm{H}$-chromenes to $2 \mathrm{H}$-chromen-2-ones which proceeds through the formation of the corresponding benzopyrylium salts $[17,18]$.<smiles>N=c1oc2ccccc2cc1C(N)=O</smiles>

1<smiles>NC(=O)c1cc2ccccc2[o+]c1N</smiles>

17<smiles>N#[W]</smiles><smiles>COOCCN=[V]</smiles><smiles>C=CCNC1(N)Oc2ccccc2C=C1C(N)=O</smiles>

$18 x$<smiles>[X]C(=O)c1ccccc1N</smiles><smiles>[X]C(=O)c1ccccc1N=c1oc2ccccc2cc1C(N)=O</smiles>

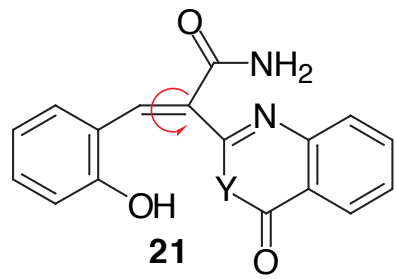

19

Path B:

intermolecular<smiles>[X]C(=O)c1ccccc1NC(=O)C1CC2C=CC(C2)C1C(N)=O</smiles>

26<smiles>[X]C(=O)c1ccccc1NC(=O)/C(=C\c1ccccc1O)C(N)=O</smiles>

27<smiles>[X]C(=O)c1ccccc1NC(=O)c1cc2ccccc2oc1=O</smiles>

28<smiles>NC(=O)c1cc2ccc(F)cc2oc1=O</smiles><smiles>NC(=O)C(=Cc1ccccc1O)c1nc2ccccc2c(=O)[Y]1=CC(N)(I)I</smiles>
if $\mathbf{X}=\mathrm{NH}_{2}, \mathbf{Y}=\mathrm{NH}$ if $\mathbf{X}=\mathrm{OH}, \mathbf{Y}=\mathrm{O}$

Scheme 5. Proposed mechanism for the transformations of 2-imino- $2 \mathrm{H}$-chromenes $\mathbf{1}$ by the action of nucleophiles under acidic conditions

The principal feature of the method for synthesis of 2-(arylimino)chromenes $\mathbf{1 9}$ is the use of either amine hydrochloride $[3,19,20]$ or benzopyrylium salts of type 17 [3]. Finally, we found a different methodology [4] based on using glacial acetic acid for in situ formation of the corresponding salts, their reaction and subsequent removal of the ammonia released. 


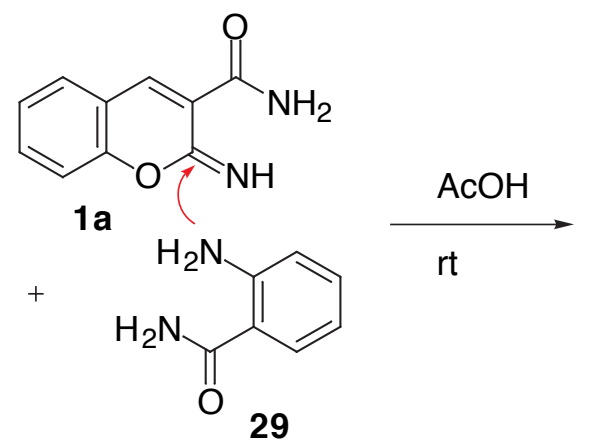<smiles>CCCN=c1oc2ccccc2cc1C(N)=O</smiles>

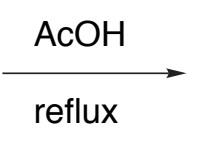<smiles>O=c1oc2ccccc2cc1-c1nc2ccccc2c(=O)[nH]1</smiles>

Scheme 6. Synthesis and rearrangement of 2-(arylimino)chromene 30 into 3-(quinazolin-2-yl)-2Hchromen-2-one (7a) under acidic anhydrous conditions

As shown in Schemes 6-10, syntheses of the desired 2-(arylimino)chromenes 30, 31, 39 and 41 were finally performed by adding equivalent amounts of the corresponding 2-iminochromene derivatives 1 to a solution of anthranilates 29, 2, 38 or benzohydrazide (11) in glacial acetic acid. After stirring the reaction mixture at room temperature, products were precipitated and subsequently isolated, purified, characterized and used for further transformations.
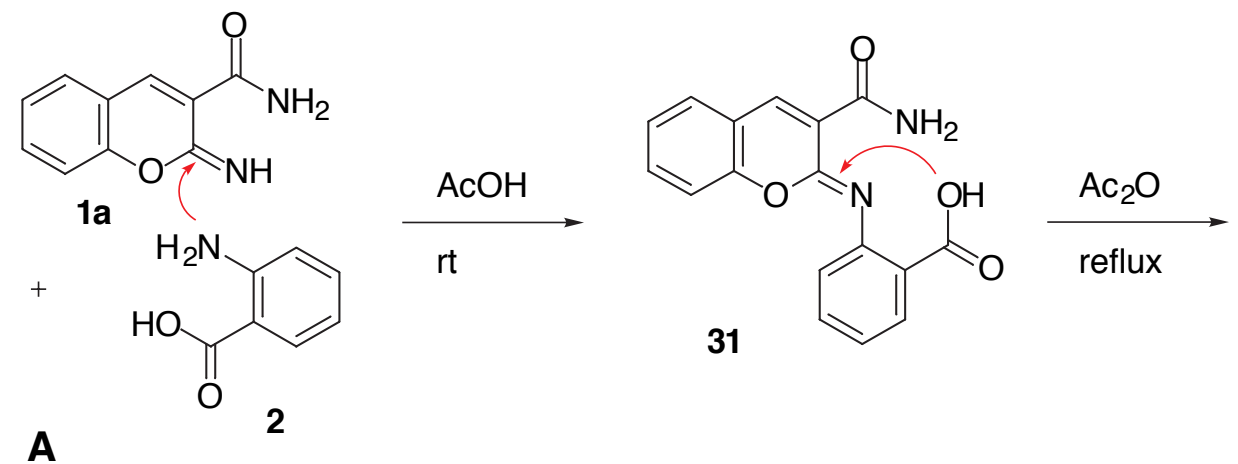<smiles>O=c1oc2ccccc2cc1-c1nc2ccccc2c(=O)o1</smiles>

A

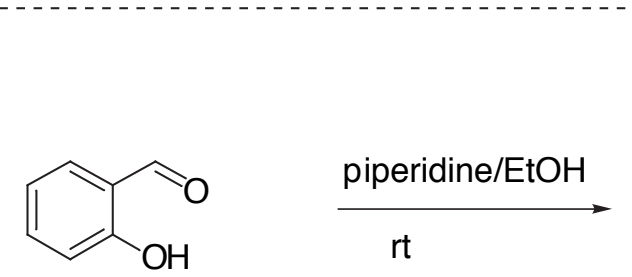

9a<smiles>N=c1oc2ccccc2cc1-c1nc2ccccc2c(=O)o1</smiles>

34

B

Scheme 7. Synthesis and rearrangement of 2-(arylimino)chromene 31 into 2-(2-oxo-2H-chromen-3yl)-4H-3,1-benzoxazin-4-one (32) under acidic anhydrous conditions

It was found that in acidic anhydrous media (glacial acetic acid or acetic anhydride), 2-(Nsubstituted imino)chromenes $\mathbf{3 0}$ and $\mathbf{3 1}$ reacted intramolecularly ( $c f$. Scheme 5, path A) to produce expected derivatives 7a (Scheme 6) and $\mathbf{3 2}$ (Scheme 7A) in good yields. 


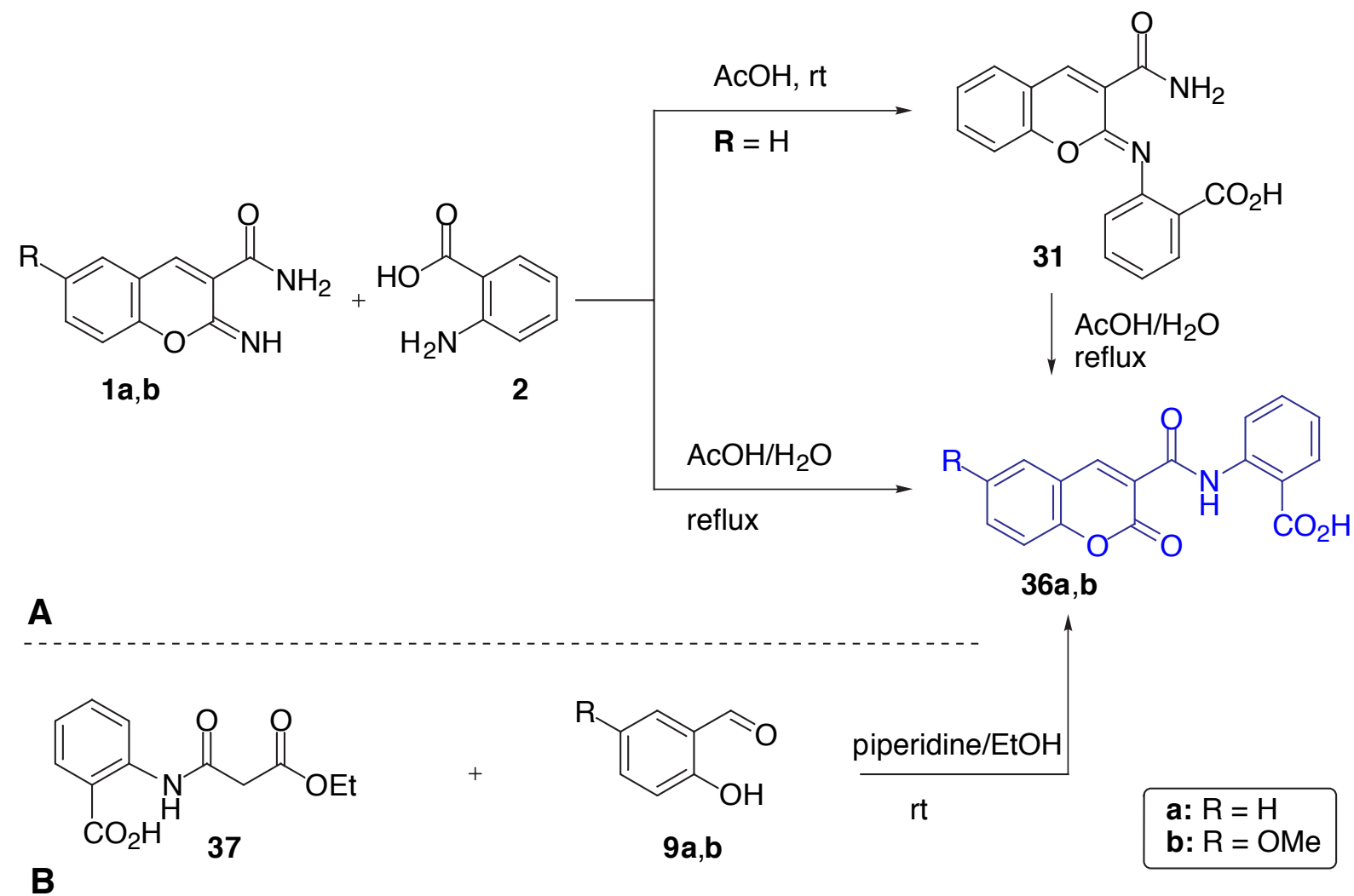

Scheme 8. Synthesis of $N$-aryl-2-oxo-2H-chromene-3-carboxamides 36 in aqueous acidic media

The reaction between imines $\mathbf{1 a}, \mathbf{b}$ and $\mathbf{2}$ in aqueous acidic media ( $80 \%$ acetic acid) (Scheme $8 \mathrm{~A}$ ) proceeded differently. Refluxing in this solvent for $2 \mathrm{~h}$ gave $\mathrm{N}$-(2-carboxyphenyl)-2-oxo- $2 \mathrm{H}$ chromene-3-carboxamides 36a,b. A mechanism that accounts for the products is detailed in Scheme 5, path B. To prove that mechanism, a reaction between 1a and $\mathbf{2}$ (Scheme $8 \mathrm{~A}$ ) was initially performed in acetic acid at room temperature. It took place without iminolactone ring opening and furnished expected intermediate 31, which was converted into compound 36a by further boiling in aqueous acetic acid. For unambiguous structure elucidation, 2-(2-oxo- $2 H$-chromen-3-yl)-4H-3,1-benzoxazin-4one 32 [21] and $N$-aryl-2-oxo- $2 H$-chromene-3-carboxamides 36a,b were also prepared independently from 2-(cyanomethyl)-4H-3,1-benzoxazin-4-one 33 [22] or ethyl 2'-carboxymalonanilate 37 [23] and salicylaldehydes 9 as depicted in Schemes 7B and 8B.

Taking into consideration the results observed for synthesis of $\mathrm{N}$-aryl-2-oxo- $2 \mathrm{H}$-chromene-3carboxamides 36 (Scheme 8A), we examined the possibility of rearrangement of 2-(arylimino)- $2 \mathrm{H}$ chromene-3-carboxamide 39 into $\mathrm{N}$-aryl-2-oxo- $2 \mathrm{H}$-chromene-3-carboxamide $\mathbf{4 0}$ by the action of water as $O$-nucleophile (Scheme 9). However, compound $\mathbf{4 0}$ was not detected presumably due to simple hydrolysis ( $c f$. Scheme 5, path B), which took place to furnish the known 2-oxo-2 $H$-chromene-3carboxamide 25 [9]. 

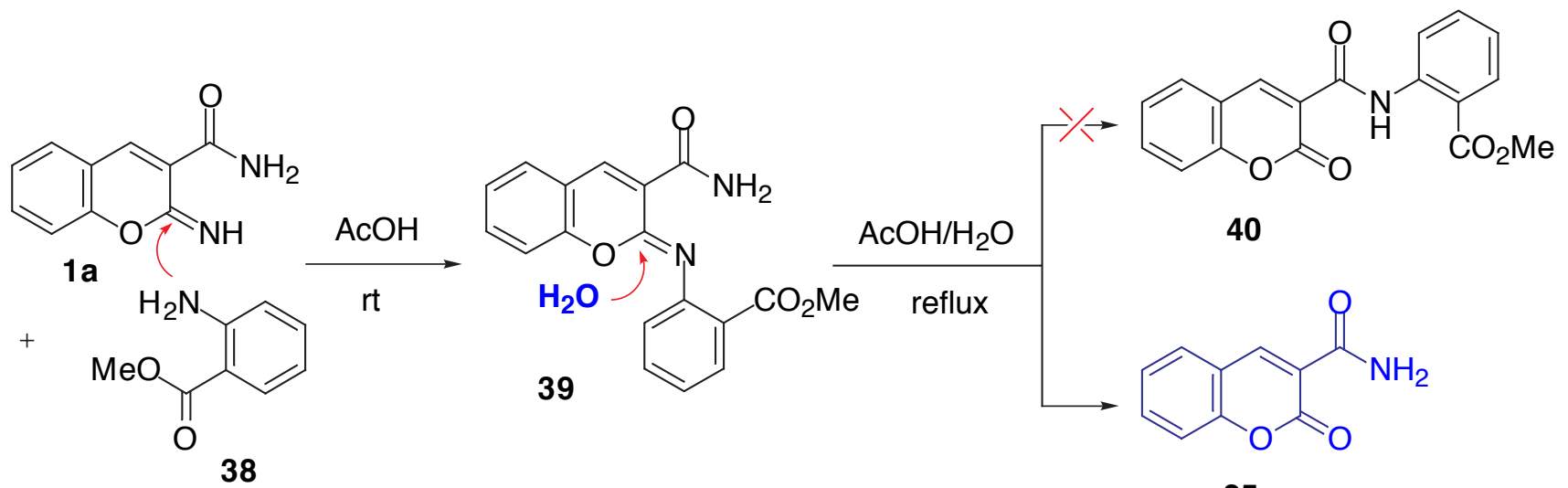

25

Scheme 9. Attempted synthesis of $\mathrm{N}$-aryl-2-oxo- $2 \mathrm{H}$-chromene-3-carboxamide $\mathbf{4 0}$ using $\mathrm{H}_{2} \mathrm{O}$ as $\mathrm{O}$ nucleophile

As a further development of the methodology outlined in Scheme 5, path A, a new approach to 2oxo-3-(5-aryl-1,3,4-oxadiazol-2-yl)-2H-chromenes of type 45 was elaborated [4e].<smiles>N=c1oc2c(cc1C(N)=O)C=C[R]C=C2</smiles>

11

41a,b

42a,b<smiles>NC(=O)C(=Cc1ccccc1O)c1nnc(-c2ccccc2)o1</smiles>

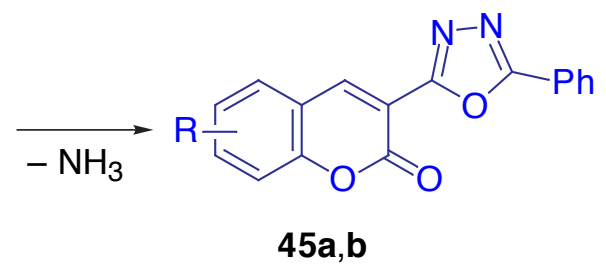

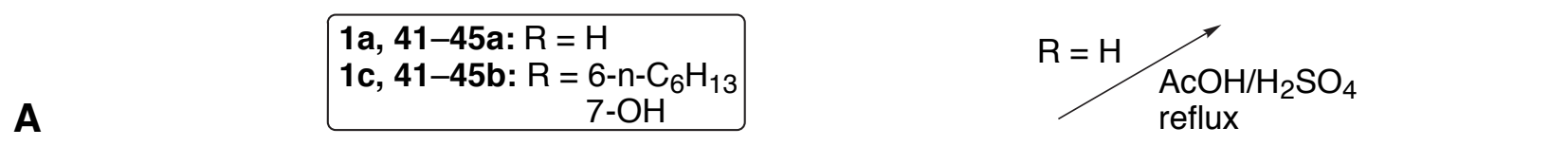

B<smiles>N/C(=N\NC(=O)c1ccccc1)c1cc2ccccc2oc1=O</smiles>

12

Scheme 10. Synthesis and rearrangement of 2-( $N$-aroylhydrazono)-2H-chromene-3-carboxamides 41 into 1,3,4-oxadiazolylchromenes $\mathbf{4 5}$ 
As exemplified in Scheme 10 (path A), the procedure was based on the rearrangement of 2-(Naroylhydrazono)- $2 \mathrm{H}$-chromene-3-carboxamides 41 , which are readily obtained by the reaction of 2 imino- $2 H$-chromene-3-carboxamides 1 with benzohydrazide $(\mathbf{1} \mathbf{1})$ in an acidic medium. Oxadiazolylchromene 45a was also synthesized separately from amide-hydrazone $\mathbf{1 2}$ ( $c f$. Scheme 2) by refluxing it in $\mathrm{AcOH} / \mathrm{H}_{2} \mathrm{SO}_{4}$ mixture (Scheme 10, pat B). Furthermore, as part of our program on structure-activity relationship studies of different heterocycles as potential tyrosine kinase inhibitors [24], we were especially interested in a short and selective entry into heterocyclic compounds comprising 2-imino- or 2-oxo- $2 \mathrm{H}$-chromene and tetrahydrobenzo[b]thiophene moieties. In our synthetic approach to heterocycles of this type $[4 \mathrm{f}, \mathrm{g}]$ we also applied the approach summarized in Scheme 5, path A.

\section{Conclusion}

The results obtained in the study of the rearrangements of 2-imino- $2 \mathrm{H}$-chromene-3-carboxamides with different $N$-nucleophiles clearly indicate that the reactions studied follow the mechanisms described in Schemes 1 and 5. Finally, this work opened a new avenue for the synthesis of a variety of new 3-hetaryl substituted 2-oxo- $2 \mathrm{H}$-chromene derivatives.

\section{Experimental}

\section{General}

Melting points $\left({ }^{\circ} \mathrm{C}\right)$ were measured on a Büchi melting point apparatus and are uncorrected. Thin layer chromatography (TLC) was performed on aluminum sheets precoated with silica gel (Merck, Kieselgel 60 F-254). ${ }^{1} \mathrm{H}-\mathrm{NMR}$ spectra were recorded on Bruker WP-100 SY, Bruker DPX-250, Bruker AMX-400 or Varian WXR-400 spectrometers in DMSO- $d_{6}$ or DMSO- $d_{6}-\mathrm{CDCl}_{3}$ using TMS as an internal standard (chemical shifts in $\delta \mathrm{ppm}$ ). Mass spectra (MS) were obtained with Finnigan MAT4615B spectrometer at an ionization potential of $70 \mathrm{eV}$. Combustion analyses of all compounds synthesized gave satisfactory microanalytical data. Infrared spectra (IR) were recorded in $\mathrm{KBr}$ pellets on Nicolet Protege 460 FT-IR or an IBM 486 computer-controlled Specord M-80 spectrometers.

2-Imino-2 $\mathrm{H}$-chromene derivatives $\mathbf{1 a}-\mathbf{c}$ were prepared $\left(\mathbf{1 a}(\mathrm{R}=\mathrm{H}\right.$; refs. $[9,25]) ; \mathbf{1 b}\left(\mathrm{R}=6-\mathrm{OCH}_{3}\right.$; ref. [26]); $1 \mathrm{c}\left(\mathrm{R}=6-\mathrm{OH}, 7-n-\mathrm{C}_{6} \mathrm{H}_{13}\right.$; ref. [4b]) by condensing cyanoacetamide with salicylaldehydes $\mathbf{9 a}-\mathbf{c}$ in ethanol at room temperature using piperidine as a catalyst to form the expected imino compounds 1a-c.

(4-Oxo-3,4-dihydroquinazolin-2-yl)acetonitrile (8) [10], 2-oxo-2H-chromene-3-thiocarboxamide (13) [13], 1-amino-4,6-dimethyl-2(1H)-oxopyridine-3-carbonitrile (15) [27], (4-oxo-4H-3,1benzoxazin-2-yl)acetonitrile (33) [22], ethyl 2'-carboxymalonanilate 37 [23] and salicylaldehyde 9c [28] were prepared by known literature procedures. 
Solvents were purified by conventional methods [29]. Starting materials, anthranilic acid (2), salicylaldehydes $(\mathbf{9 a}, \mathbf{b})$, benzohydrazide (11), anthranilamide (29) and methyl anthranilate (38) were purchased from Aldrich ${ }^{\circledR}$.

2-(2-Oxo-2H-chromen-3-yl)quinazolin-4(3H)-one (7a):

Method A: A mixture of $\mathbf{1 a}(282 \mathrm{mg}, 1.5 \mathrm{mmol})$ and anthranilic acid $\mathbf{2}(370 \mathrm{mg}, 2.7 \mathrm{mmol})$ in dry and degassed toluene $(10 \mathrm{~mL})$ was refluxed for 5-6 h (TLC monitoring) through a column equipped with a Dean-Stark trap containing a thimble filled with $4 \AA$ molecular sieves which had been activated at 325 ${ }^{\circ} \mathrm{C}$ for $24 \mathrm{~h}$. In the course of the reaction, ammonia was released. The mixture was cooled and a yellow precipitate was filtered off and recrystallized from $\mathrm{DMF} / \mathrm{BuOH}$ to afford $205 \mathrm{mg}$ (47\%) of 7a: M.p. 275-277 ${ }^{\circ} \mathrm{C}$ (lit. [5] m.p. $243{ }^{\circ} \mathrm{C}$; lit. [6] m.p. $245^{\circ} \mathrm{C}$ ). ${ }^{1} \mathrm{H}-\mathrm{NMR}\left(400 \mathrm{MHz}, \mathrm{DMSO}-d_{6}\right): \delta 7.49$ (dddd, $1 \mathrm{H}, J=8.3,7.8,0.6,0.4 \mathrm{~Hz}, \operatorname{Ar} H) ; 7.58(\mathrm{~m}, 2 \mathrm{H}, \operatorname{Ar} H) ; 7.79(\mathrm{~m}, 2 \mathrm{H}, \operatorname{Ar} H) ; 7.90(\mathrm{~m}, 1 \mathrm{H}, \operatorname{ArH}) ; 8.03$ (ddd, $1 \mathrm{H}, J=7.7,1.6,0.4 \mathrm{~Hz}, \operatorname{Ar} H) ; 8.18(\mathrm{~m}, 1 \mathrm{H}, \mathrm{Ar} H) ; 8.97$ (s, 1H, H-4); 12.07 (br s, 1H, NH). IR $(\mathrm{KBr}), \mathrm{cm}^{-1}: v 3254(\mathrm{NH}), 1706(\mathrm{C}=\mathrm{O}$, lactone), 1690 (C=O, amide), 1606, 1579, 1553, 1465. MS (EI, $70 \mathrm{eV}) \mathrm{m} / z$ (rel.\%): $290\left(\mathrm{M}^{+}, 83\right), 262$ (17), 145 (8), 119 (100), 92 (19), 76 (5), 53 (10). Anal. Calcd for $\mathrm{C}_{17} \mathrm{H}_{10} \mathrm{~N}_{2} \mathrm{O}_{3}$ (290.28): C, 70.34; H, 3.47; N, 9.65. Found: C, 70.29; H, 3.61; N, 9.79.

Method B: To a well stirred solution of quinazoline-2-acetonitrile 8 [10] (185 $\mathrm{mg}, 1 \mathrm{mmol})$ in propan2-ol $(5 \mathrm{~mL})$ was added the equivalent amount of salicylaldehyde $9 \mathbf{a}(0.1 \mathrm{~mL})$ and a few drops of piperidine as a catalyst. The reaction mixture was stirred at room temperature for $2 \mathrm{~h}$. The precipitated product was filtered off, washed with propan-2-ol and recrystallized from butan-1-ol to afford $214 \mathrm{mg}$ (74\%) of 2-(2-imino-2H-chromen-3-yl)quinazolin-4(3H)-one (10a): M.p. $225-228{ }^{\circ} \mathrm{C} .{ }^{1} \mathrm{H}-\mathrm{NMR}(100$ MHz, DMSO- $\left.d_{6}\right): \delta$ 7.22-7.28 (m, 2H, $\left.\mathrm{Ar} H\right) ; 7.46(\mathrm{dd}, 1 \mathrm{H}, J=8.3,7.8 \mathrm{~Hz}, \mathrm{ArH}) ; 7.52-7.73(\mathrm{~m}, 4 \mathrm{H}$, $\operatorname{Ar} H) ; 8.14(\mathrm{~d}, 1 \mathrm{H}, J=7.8 \mathrm{~Hz}, \operatorname{Ar} H) ; 8.96(\mathrm{~s}, 1 \mathrm{H}, H-4) ; 8.98(\mathrm{~s}, 1 \mathrm{H}, \mathrm{C}=\mathrm{NH}) ; 14.04$ (br s, 1H, NH). IR $(\mathrm{KBr}), \mathrm{cm}^{-1}: v 3435(\mathrm{NH}), 3319(\mathrm{NH}), 3060,1689(\mathrm{C}=\mathrm{O}$, amide), $1678(\mathrm{C}=\mathrm{N}), 1655,1599$. MS (EI, 70 eV) $m / z$ (rel.\%): 289 (M+, 76), 272 (100), 171 (10), 146 (30), 119 (62), 92 (19), 77 (6), 63 (9). A solution of the corresponding $\mathbf{1 0 a}(189 \mathrm{mg}, 0.65 \mathrm{mmol})$ in $10 \mathrm{~mL}$ of a mixture of ethanol/water/ 32\% hydrochloric acid $(30: 1: 1, \mathrm{v} / \mathrm{v} / \mathrm{v})$ was refluxed with vigorous stirring for $1 \mathrm{~h}$. After cooling to room temperature, the precipitated product was filtered off and recrystallized from $\mathrm{DMF} / \mathrm{BuOH}$ to afford $169 \mathrm{mg}(89 \%)$ of the title compound $7 \mathbf{a}$.

Method C: A solution of $30(309 \mathrm{mg}, 1.0 \mathrm{mmol})$ in glacial $(99.8 \%)$ acetic acid $(5 \mathrm{~mL})$ was refluxed for $30 \mathrm{~min}$. The mixture was cooled, the yellow precipitate was filtered off, washed with water and recrystallized from $\mathrm{DMF} / \mathrm{BuOH}$ to afford $201 \mathrm{mg}$ (70\%) of 7a. According to ${ }^{1} \mathrm{H}-\mathrm{NMR}$ and IR spectral data as well as the melting points, the products obtained by Methods $A, B$ and $C$ are identical.

2-(6-Methoxy-2-oxo-2H-chromen-3-yl)quinazolin-4(3H)-one (7b): 
Method A: The reaction of $\mathbf{1} \mathbf{b}(327 \mathrm{mg}, 1.5 \mathrm{mmol})$ was performed using the reaction conditions described for preparation of 7a to give $187 \mathrm{mg}(39 \%)$ of $\mathbf{7 b}:{ }^{1} \mathrm{H}-\mathrm{NMR}\left(100 \mathrm{MHz}, \mathrm{DMSO}-d_{6}\right): \delta 3.87$ (s, 3H, $\left.\mathrm{OCH}_{3}\right)$; 7.26-8.06 (m, 6H, ArH); 8.18 (d, 1H, J = 8.0 Hz, ArH); 8.99 (s, 1H, H-4); 12.00 (br s, 1H, NH). IR (KBr), cm $\mathrm{cm}^{-1}: \mathrm{v} 3242(\mathrm{NH}), 3065,3010,2971,1706$ (C=O, lactone), 1683 (C=O, amide),

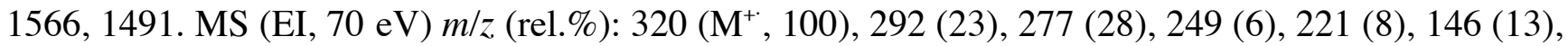
119 (95), 90 (21), 76 (17). Anal. Calcd for $\mathrm{C}_{18} \mathrm{H}_{12} \mathrm{~N}_{2} \mathrm{O}_{4}$ (320.31): C, 67.50; H, 3.77; N, 8.74. Found: C, $67.71 ; \mathrm{H}, 3.81 ; \mathrm{N}, 8.69$.

Method B: The synthesis of $\mathbf{1 0 b}$ was performed starting from $\mathbf{8}(185 \mathrm{mg}, 1 \mathrm{mmol})$ and $\mathbf{9 b}(0.15 \mathrm{~mL})$ using the reaction conditions described for preparation of 10a to give $227 \mathrm{mg}(71 \%)$ of 10b: ${ }^{1} \mathrm{H}-\mathrm{NMR}$ $\left(100 \mathrm{MHz}, \mathrm{DMSO}-d_{6}\right): \delta 3.79\left(\mathrm{~s}, 3 \mathrm{H}, \mathrm{OCH}_{3}\right) ; 7.17(\mathrm{~s}, 1 \mathrm{H}, \mathrm{ArH}) ; 7.41-7.93(\mathrm{~m}, 5 \mathrm{H}, \mathrm{ArH}) ; 8.12(\mathrm{~d}, 1 \mathrm{H}$, $J=7.7 \mathrm{~Hz}, \mathrm{Ar} H) ; 8.85(\mathrm{~s}, 1 \mathrm{H}, H-4) ; \mathrm{C}=\mathrm{N} H$ and $\mathrm{N} H$ exchanged deuterium with the solvent. MS (EI, 70 eV) m/z (rel.\%): 319 (M+1, 42), 302 (100), 276 (8), 259 (6), 222 (7), 160 (8), 146 (8), 119 (14). Subsequent acid hydrolysis of $\mathbf{1 0 b}(160 \mathrm{mg}, 0.5 \mathrm{mmol})$ employing the reaction conditions described for hydrolysis of $\mathbf{1 0 a}$ afforded $130 \mathrm{mg}(81 \%)$ of $\mathbf{7 b}$. According to ${ }^{1} \mathrm{H}-\mathrm{NMR}$, IR spectral data, and the melting points, the compounds obtained by Methods $A$ and $B$ are identical.

\section{$\mathrm{N}^{2}$-Benzoyl-2-oxo-2H-chromene-3-carbohydrazonamide (12):}

Method A: A mixture of 1a (188 mg, $1 \mathrm{mmol})$ and benzohydrazide (11) (136 mg, $1 \mathrm{mmol})$ in butan-1ol (5 mL) was refluxed for 15-30 min (TLC monitoring) while ammonia was released. Then the mixture was cooled, the precipitate was filtered off and washed with hot ethanol to afford $267 \mathrm{mg}$ (87\%) of 12: M.p. $187-189{ }^{\circ} \mathrm{C} .{ }^{1} \mathrm{H}-\mathrm{NMR}\left(100 \mathrm{MHz}, \mathrm{DMSO}-d_{6}\right)$ : $\delta 6.87$ (br s, $\left.2 \mathrm{H}, \mathrm{NH}_{2}\right) ; 7.40-7.90(\mathrm{~m}$, 9H, ArH); 8.57 (s, 1H, H-4); 10.09 (br s, 1H, CONH). IR (KBr), cm ${ }^{-1}$ v 3418, $3181(\mathrm{NH}), 1704(\mathrm{C}=\mathrm{O}$, lactone), $1682\left(\mathrm{C}=\mathrm{O}\right.$, amide), $1658(\mathrm{C}=\mathrm{N})$. Anal. Calcd for $\mathrm{C}_{17} \mathrm{H}_{13} \mathrm{~N}_{3} \mathrm{O}_{3}$ (307.30): C, 66.44; $\mathrm{H}, 4.26 ; \mathrm{N}$, 13.67. Found: C, 66.09; H, 4.51; N, 13.89 .

Method B: To a cold $\left(0{ }^{\circ} \mathrm{C}\right)$ solution of 2-oxo-2H-chromene-3-carbothioamide 13 [13] (2.05 g, 10 $\mathrm{mmol})$ in DMF $(25 \mathrm{~mL})$ dry acetone $(15 \mathrm{~mL})$ followed by iodomethane $(2 \mathrm{~mL}, 32 \mathrm{mmol})$ were added. The mixture was kept for $24 \mathrm{~h}$ at a dark place. The hydroiodide precipitated was filtered off and washed with ether. Hydroiodide $(10 \mathrm{mmol})$ was suspended in 1,4-dioxane (50 $\mathrm{mL})$ and triethylamine $(1.5 \mathrm{~mL}, 10 \mathrm{mmol})$ was added. After stirring for $1 \mathrm{~h}$ at room temperature, the solvent was removed under reduced pressure and the residue was extracted with $\mathrm{CHCl}_{3}(2 \times 10 \mathrm{~mL})$. The extract was washed with ice water, dried over $\mathrm{Na}_{2} \mathrm{SO}_{4}$ and the solvent was removed in vacuo to afford $899 \mathrm{mg}(41 \%)$ of $S$ methyl 2-oxo-2H-chromene-3-carboximidothioate (14) [30]: ${ }^{1} \mathrm{H}-\mathrm{NMR}$ (250 MHz, DMSO- $\left.d_{6}\right): \delta 2.47$ (s, 3H, $\left.\mathrm{SCH}_{3}\right)$; 7.11-7.83 (m, 4H, ArH); 8.33 (s, 1H, H-4); 9.89 (s, 1H, NH). IR (KBr), cm ${ }^{-1}$ : v 3247 $(\mathrm{NH}), 1729(\mathrm{C}=\mathrm{O}$, lactone $), 1612(\mathrm{C}=\mathrm{N}), 1593$. The crude $\mathbf{1 4}$ was used without any purification in the 
following stage. The imidothioester $14(440 \mathrm{mg}, 2 \mathrm{mmol})$ and benzohydrazide (11) (275 mg, $2 \mathrm{mmol})$ were dissolved in DMF/EtOH (3/1 mixture, $10 \mathrm{~mL})$. The mixture was heated for $4 \mathrm{~h}$ at $80{ }^{\circ} \mathrm{C}$ until evolving methanethiol was detected. The solvents were removed under reduced pressure and the residue was washed with hot ethanol to afford $178 \mathrm{mg}$ (29\%) of 12. According to ${ }^{1} \mathrm{H}-\mathrm{NMR}$, IR spectral data as well as the melting points, the compounds obtained by Methods $A$ and $B$ are identical.

N-(3-Cyano-4,6-dimethyl-2(1H)-oxopyridin-1-yl)-2-oxo-2H-chromenes (16):

Amidines 16a,b were prepared from carbamoyliminochromenes 1a,b and 1-aminopyridone 15 [27] using the reaction conditions described in Method $A$ for the synthesis of $\mathbf{1 2}$.

1-[1-amino-1-(2-oxo-2H-chromen-3-yl)methylideneamino]-4,6-dimethyl-2(1H)-oxopyridine-3carbonitrile (16a):

Yield: 31\%. M.p. 291-293 ${ }^{\circ} \mathrm{C}$ (dec.). ${ }^{1} \mathrm{H}-\mathrm{NMR}\left(400 \mathrm{MHz}, \mathrm{DMSO}-d_{6}-\mathrm{CDCl}_{3}\right.$ ): $\delta 2.29\left(\mathrm{~s}, 3 \mathrm{H}, \mathrm{CH}_{3}\right.$ ); 2.36 (s, 3H, $\mathrm{CH}_{3}$ ); 6.38 (s, 1H, CH-pyridone); 7.46 (br s, $2 \mathrm{H}, \mathrm{NH}_{2}$ ); 7.48 (ddd, $1 \mathrm{H}, J=7.7,7.6,1.0 \mathrm{~Hz}$, $H-6) ; 7.55$ (dd, $1 \mathrm{H}, J=8.4,1.0 \mathrm{~Hz}, H-8) ; 7.78$ (ddd, $1 \mathrm{H}, J=8.4,7.6,1.4 \mathrm{~Hz}, H-7) ; 8.00$ (dd, $J=7.7$, $1.4 \mathrm{~Hz}, H-5) ; 8.74$ (s, $1 \mathrm{H}, H-4)$. Anal. Calcd for $\mathrm{C}_{18} \mathrm{H}_{14} \mathrm{~N}_{4} \mathrm{O}_{3}$ (334.33): C, 64.66; H, 4.22; N, 16.76. Found: C, 64.97; H, 4.34; N, 17.02 .

1-[1-amino-1-(6-methoxy-2-oxo-2H-chromen-3-yl)methylideneamino]-4,6-dimethyl-2(1H)oxopyridine-3-carbonitrile (16b):

Yield: $27 \%$. M.p. $312-314{ }^{\circ} \mathrm{C} .{ }^{1} \mathrm{H}-\mathrm{NMR}\left(400 \mathrm{MHz}, \mathrm{DMSO}-d_{6}\right): \delta 2.28\left(\mathrm{~s}, 3 \mathrm{H}, \mathrm{CH}_{3}\right) ; 2.37\left(\mathrm{~s}, 3 \mathrm{H}, \mathrm{CH}_{3}\right)$; 3.85 (s, 3H, $\left.\mathrm{OCH}_{3}\right) ; 6.21$ (s, 1H, CH-pyridone); 7.27 (dd, 1H, J = 9.1, $\left.2.9 \mathrm{~Hz}, H-7\right)$; 7.34 (d, 1H, J= $2.9 \mathrm{~Hz}, H-5) ; 7.36$ (d, $1 \mathrm{H}, J=9.1 \mathrm{~Hz}, H-8) ; 7.46$ (br s, $2 \mathrm{H}, \mathrm{NH}_{2}$ ); 8.89 (s, $\left.1 \mathrm{H}, H-4\right)$. Anal. Calcd for $\mathrm{C}_{19} \mathrm{H}_{16} \mathrm{~N}_{4} \mathrm{O}_{4}$ (364.35): C, 62.63; H, 4.43; N, 15.38. Found: C, 62.49; H, 4.58; N, 15.09.

\section{2-(Phenylimino)-2H-chromene-3-carboxamides 30, 31 and 39:}

\section{General procedure}

To a stirred solution of anthranilates $\mathbf{2 9}, \mathbf{2}$ or $\mathbf{3 8}(10 \mathrm{mmol})$ in glacial acetic acid $(15 \mathrm{~mL})$ was added an equivalent amount of the corresponding 2-imino- $2 H$-chromene derivatives $\mathbf{1 a}, \mathbf{b}$. The reaction mixture was stirred at room temperature overnight. The precipitated products were filtered off, washed with water, propan-2-ol (3 x $5 \mathrm{~mL})$, and dried in air.

2-[(2-Carbamoylphenyl)imino]-2H-chromene-3-carboxamide (30): 
Yield: 82\%. M.p. $244-246{ }^{\circ} \mathrm{C} .{ }^{1} \mathrm{H}-\mathrm{NMR}\left(250 \mathrm{MHz}, \mathrm{DMSO}-d_{6}\right): \delta$ 7.07-7.28 (m, 5H, CONH$\left.+\mathrm{Ar} H\right)$; 7.40-7.64 (m, 3H, $\mathrm{ArH})$; 7.75-7.78 (m, 2H, CONH $\left.H_{2}+\mathrm{ArH}\right) ; 7.83$ (br s, $\left.1 \mathrm{H}, \mathrm{CONH}_{2}\right) ; 8.41(\mathrm{~s}, 1 \mathrm{H}, H-4)$; 9.02 (br s, $\left.1 \mathrm{H}, \mathrm{CONH}_{2}\right)$. IR (KBr), cm ${ }^{-1}: \mathrm{v} 3392(\mathrm{NH}), 3168(\mathrm{NH}), 1640(\mathrm{C}=\mathrm{O}+\mathrm{C}=\mathrm{N})$, 1588. Anal. Calcd for $\mathrm{C}_{17} \mathrm{H}_{13} \mathrm{~N}_{3} \mathrm{O}_{3}$ (307.30): C, 66.44; H, 4.26; N, 13.67. Found: C, 66.21; H, 4.39; N, 13.89.

2-[(2-Carboxyphenyl)imino]-2H-chromene-3-carboxamide (31):

Yield: $62 \%$. M.p. $191-192{ }^{\circ} \mathrm{C} .{ }^{1} \mathrm{H}-\mathrm{NMR}\left(400 \mathrm{MHz}, \mathrm{DMSO}-d_{6}\right): \delta 6.98(\mathrm{~d}, 1 \mathrm{H}, J=8.1 \mathrm{~Hz}, \operatorname{Ar} H)$; $7.10-$ $7.22(\mathrm{~m}, 3 \mathrm{H}, \mathrm{ArH}) ; 7.41-7.48(\mathrm{~m}, 2 \mathrm{H}, \mathrm{ArH}) ; 7.62$ (br s, $\left.1 \mathrm{H}, \mathrm{CONH}_{2}\right) ; 7.64(\mathrm{dd}, 1 \mathrm{H}, J=8.2,0.6 \mathrm{~Hz}$, $\operatorname{Ar} H) ; 7.90(\mathrm{dd}, 1 \mathrm{H}, J=8.5,0.6 \mathrm{~Hz}, \mathrm{ArH}) ; 8.42$ (s, 1H, H-4); 9.21 (s, 1H, CONH$\left.{ }_{2}\right)$. IR (KBr), $\mathrm{cm}^{-1}: v$ $3300\left(\mathrm{NH}_{2}+\mathrm{OH}\right), 3160(\mathrm{NH}), 1700(\mathrm{C}=\mathrm{O}$, acid), $1670(\mathrm{C}=\mathrm{O}$, amide). MS (EI, $70 \mathrm{eV}) \mathrm{m} / \mathrm{z}$ (rel.\%): 308 $\left(\mathrm{M}^{+}, 46\right), 291$ (55), 264 (37), 248 (86), 220 (100), 189 (43), 173 (36), 145 (54), 119 (42), 89 (34), 65 (28), 44 (36). Anal. Calcd for $\mathrm{C}_{17} \mathrm{H}_{12} \mathrm{~N}_{2} \mathrm{O}_{4}$ (308.30): C, 66.23; H, 3.92; N, 9.09. Found: C, 66.19; H, $4.01 ; \mathrm{N}, 9.14$.

2-\{[(2-Methoxycarbonyl)phenyl]imino\}-2H-chromene-3-carboxamide (39):

Yield: $68 \%$. M.p. $214-217{ }^{\circ} \mathrm{C} .{ }^{1} \mathrm{H}-\mathrm{NMR}\left(250 \mathrm{MHz}, \mathrm{DMSO}-d_{6}\right): \delta 3.71\left(\mathrm{~s}, 3 \mathrm{H}, \mathrm{OCH}_{3}\right) ; 6.98(\mathrm{~d}, 1 \mathrm{H}, J=$ 8.0 Hz, ArH); 7.17-7.26 (m, 3H, ArH); 7.45-7.52 (m, 2H, ArH); 7.73 (d, 1H, J=8.2 Hz, ArH); 7.76 (br s, $\left.1 \mathrm{H}, \mathrm{CONH}_{2}\right) ; 7.88(\mathrm{~d}, 1 \mathrm{H}, J=8.3 \mathrm{~Hz}, \mathrm{ArH}) ; 8.52$ (s, $\left.1 \mathrm{H}, H-4\right) ; 9.17$ (br s, $1 \mathrm{H}, \mathrm{CON} H_{2}$ ). IR $(\mathrm{KBr}), \mathrm{cm}^{-1}: \vee 3424(\mathrm{NH}), 3272(\mathrm{NH}), 1716(\mathrm{C}=\mathrm{O}$, ester), 1688 (C=O, amide), 1608. Anal. Calcd for $\mathrm{C}_{18} \mathrm{H}_{14} \mathrm{~N}_{2} \mathrm{O}_{4}$ (322.31): C, 67.07; H, 4.38; N, 8.69. Found: C, 66.79; H, 3.99; N, 8.43.

2-(2-Oxo-2H-chromen-3-yl)-4H-3,1-benzoxazin-4-one (32):

Method A: A solution of 2-[(2-carboxyphenyl)imino]-2H-chromene-3-carboxamide (31) (310 mg, 1 mmol) in acetic anhydride $(3 \mathrm{~mL})$ was refluxed for $30 \mathrm{~min}$. After completed reaction, the mixture was cooled and the precipitate formed was filtered off, washed with water, cold propan-2-ol ( $2 \times 5 \mathrm{~mL})$ and recrystallized from benzene to give $224 \mathrm{mg}$ (77\%) of 32: M.p. 203-204 ${ }^{\circ} \mathrm{C}$ (lit. [5] m.p. $197{ }^{\circ} \mathrm{C}$; lit. [21b] m.p. $\left.195{ }^{\circ} \mathrm{C}\right) .{ }^{1} \mathrm{H}-\mathrm{NMR}\left(100 \mathrm{MHz}, \mathrm{DMSO}-d_{6}\right): \delta$ 7.38-7.43 (m, 2H, ArH); 7.65-7.74 (m, 3H, $\operatorname{Ar} H) ; 7.92-7.96(\mathrm{~m}, 2 \mathrm{H}, \operatorname{Ar} H) ; 8.20(\mathrm{~d}, 1 \mathrm{H}, J=7.9 \mathrm{~Hz}, \operatorname{Ar} H) ; 8.86(\mathrm{~s}, 1 \mathrm{H}, H-4)$. IR (KBr), $\mathrm{cm}^{-1}: \mathrm{v}$ 3063, $1749(\mathrm{C}=\mathrm{O})$, 1599. Anal. Calcd for $\mathrm{C}_{17} \mathrm{H}_{9} \mathrm{NO}_{4}$ (291.26): C, 70.10; H, 3.11; N, 4.81. Found: C, $69.89 ; \mathrm{H}, 3.34 ; \mathrm{N}, 5.11$.

Method B: 2-(2-Imino-2H-chromen-3-yl)-4H-3,1-benzoxazin-4-one (34) was synthesized from (4-oxo4H-3,1-benzoxazin-2-yl)-2-acetonitrile (33) [23] (190 mg, $1 \mathrm{mmol}$ ) and 2-hydroxybenzaldehyde (9a) $(0.1 \mathrm{~mL})$ using the reaction conditions described in Method B for the synthesis of 10a to give $177 \mathrm{mg}$ 
(61\%) of iminochromene 34. The compound 34 was used without any purification in the following reaction. Acid hydrolysis of $\mathbf{3 4}(130 \mathrm{mg}, 0.45 \mathrm{mmol})$ employing the reaction conditions described for conversion of 10a into 7a afforded $77 \mathrm{mg}(59 \%)$ of 32. ${ }^{1} \mathrm{H}-\mathrm{NMR}$, IR spectral data, and melting points confirm identity of the compounds obtained by Methods $A$ and $B$.

N-aryl-2-oxo-2H-chromene-3-carboxamides 36a,b:

\section{General procedures}

Method A: A mixture of $\mathbf{1 a}$ or $\mathbf{1 b}(1.5 \mathrm{mmol})$ and anthranilic acid 2 (275 $\mathrm{mg}, 2 \mathrm{mmol})$ in aqueous $(80 \%)$ acetic acid $(10 \mathrm{~mL})$ was refluxed for $2 \mathrm{~h}$. After the reaction finished, the mixture was cooled and the precipitate was filtered off, washed with water and cold propan-2-ol ( $2 \times 5 \mathrm{~mL})$. The products obtained were recrystallized from an appropriate solvent.

Method B: To a well stirred solution of ethyl 2'-carboxymalonanilate (37) [23] (4 mmol) in ethanol (10 $\mathrm{mL}$ ) was added an equivalent amount of salicylaldehydes $9 \mathbf{a}$ or $\mathbf{9 b}$ and a few drops of piperidine as a catalyst. The reaction mixture was stirred at room temperature for ca. 1 day and then poured into water. The products precipitated were filtered off and recrystallized from an appropriate solvent.

\section{N-(2-Carboxyphenyl)-2-oxo-2H-chromene-3-carboxamide (36a):}

Yields: 82\% (Method A) and 67\% (Method B) (recrystallized from AcOH). M.p. 275-276 ${ }^{\circ} \mathrm{C}$ (lit. [5,21b] m.p. $\left.279{ }^{\circ} \mathrm{C}\right) .{ }^{1} \mathrm{H}-\mathrm{NMR}\left(400 \mathrm{MHz}, \mathrm{DMSO}-d_{6}\right): \delta 7.15(\mathrm{dd} 1 \mathrm{H}, J=8.0,8.0 \mathrm{~Hz}, \mathrm{ArH}) ; 7.39(\mathrm{~m}$, $2 \mathrm{H}, \operatorname{Ar} H) ; 7.56(\mathrm{dd}, 1 \mathrm{H}, J=8.0,8.0 \mathrm{~Hz}, \operatorname{Ar} H) ; 7.73(\mathrm{dd}, 1 \mathrm{H}, J=7.9,7.9 \mathrm{~Hz}, \operatorname{Ar} H) ; 7.94(\mathrm{~d}, 1 \mathrm{H}, J=$ $8.2 \mathrm{~Hz}, \operatorname{Ar} H) ; 8.05(\mathrm{~d}, 1 \mathrm{H}, J=8.2 \mathrm{~Hz}, \operatorname{ArH}) ; 8.65$ (d, $1 \mathrm{H}, J=8.3 \mathrm{~Hz}, \operatorname{ArH}) ; 8.85$ (s, $1 \mathrm{H}, H-4) ; 13.52$ (br s, 1H, NH). IR (KBr), cm ${ }^{-1}$ : v $3266(\mathrm{NH}), 3032(\mathrm{CH}), 1731(\mathrm{C}=\mathrm{O}), 1696(\mathrm{C}=\mathrm{O}), 1673(\mathrm{C}=\mathrm{O}), 1608$ $(\mathrm{C}=\mathrm{C})$. Anal. Calcd for $\mathrm{C}_{17} \mathrm{H}_{11} \mathrm{NO}_{5}$ (309.28): C, 66.02; H, 3.58; N, 4.53. Found: C, 66.32; H, 3.78; N, 4.72.

N-(2-Carboxyphenyl)-6-methoxy-2-oxo-2H-chromene-3-carboxamide (36b):

Yields: 69\% (Method A) and 59\% (Method B) (recrystallized from butan-1-ol). M.p. 124-125 ${ }^{\circ} \mathrm{C} .{ }^{1} \mathrm{H}-$ NMR (400 MHz, DMSO-d $)_{6}$ : $\delta 3.95\left(\mathrm{~s}, 3 \mathrm{H}, \mathrm{OCH}_{3}\right)$; 7.14-7.32 (m, 4H, ArH); $7.42(\mathrm{~d}, 1 \mathrm{H}, J=8.2 \mathrm{~Hz}$, $\operatorname{Ar} H) ; 8.01(\mathrm{~d}, 1 \mathrm{H}, J=8.0 \mathrm{~Hz}, \operatorname{Ar} H) ; 8.60(\mathrm{~d}, 1 \mathrm{H}, J=8.0 \mathrm{~Hz}, \operatorname{Ar} H) ; 8.89$ (s, $1 \mathrm{H}, H-4) ; 13.20(\mathrm{~s}, 1 \mathrm{H}$, $\mathrm{NH})$. IR (KBr), cm $\mathrm{cm}^{-1}$ v $3287(\mathrm{NH}), 2952(\mathrm{CH}), 1726(\mathrm{C}=\mathrm{O}), 1694(\mathrm{C}=\mathrm{O}), 1675(\mathrm{C}=\mathrm{O}), 1614(\mathrm{C}=\mathrm{C})$. Anal. Calcd for $\mathrm{C}_{18} \mathrm{H}_{13} \mathrm{NO}_{6}$ (339.31): C, 63.72; H, 3.86; N, 4.13. Found: C, 64.00; H, 4.03; N, 3.91. 
A solution of 39 (482 $\mathrm{mg}, 1.5 \mathrm{mmol})$ in aqueous (80\%) acetic acid $(10 \mathrm{~mL})$ was refluxed for $2 \mathrm{~h}$. After the reaction was complete, the mixture was cooled and the precipitate was filtered off, washed with water and cold propan-2-ol $(5 \mathrm{~mL})$. The product obtained was recrystallized from ethanol to give 228 mg $(81 \%)$ of 25: M.p. $279-280{ }^{\circ} \mathrm{C}$ (lit. [9] m.p. 280-282 ${ }^{\circ} \mathrm{C}$ ). ${ }^{1} \mathrm{H}-\mathrm{NMR}$ (400 MHz, DMSO- $\left.d_{6}\right): \delta 7.47$ (ddd, $1 \mathrm{H}, J=7.7,7.7,1.0 \mathrm{~Hz}, H-6) ; 7.53$ (dd, $1 \mathrm{H}, J=8.4,1.0 \mathrm{~Hz}, H-8$ ); 7.79 (ddd, $1 \mathrm{H}, J=8.4,7.7$, $1.6 \mathrm{~Hz}, H-7) ; 7.96$ (br s, $1 \mathrm{H}, \mathrm{CONH}_{2}$ ); 8.00 (dd, $J=7.7,1.6 \mathrm{~Hz}, H-5$ ); 8.12 (br s, $1 \mathrm{H}, \mathrm{CONH}_{2}$ ); 8.90 (s, 1H, H-4). Anal. Calcd for $\mathrm{C}_{10} \mathrm{H}_{7} \mathrm{NO}_{3}$ (189.17): C, 63.49; H, 3.73; N, 7.40. Found: C, 63.54; H, 3.71; N, 7.51 .

2-oxo-3-(5-phenyl-1,3,4-oxadiazol-2-yl)-2H-chromene (45a):

Method A: To a stirred solution of 2-imino-2H-chromene $1 \mathrm{a}(1.88 \mathrm{~g}, 10 \mathrm{mmol})$ in glacial acetic acid $(25 \mathrm{~mL})$ was added an equivalent amount of benzohydrazide (11) (1.36 g, $10 \mathrm{mmol})$ and 2 drops of $\mathrm{H}_{2} \mathrm{SO}_{4}$. The reaction mixture was warmed to $40{ }^{\circ} \mathrm{C}$ and stirred at room temperature for $\mathrm{ca}$. $3 \mathrm{~h}$. The precipitated product was filtered off, washed with ethyl acetate $(3 \times 5 \mathrm{~mL})$ and recrystallized from propan-2-ol to yield $2.82 \mathrm{~g}(92 \%)$ of 2-( $N$-benzoylhydrazono)- $2 H$-chromene 41a: M.p. $226-227{ }^{\circ} \mathrm{C}$. ${ }^{1} \mathrm{H}-\mathrm{NMR}\left(100 \mathrm{MHz}, \mathrm{DMSO}-d_{6}\right): \delta$ 7.22-7.90 (m, 9H, ArH); $7.98\left(\mathrm{~s}, 1 \mathrm{H}, \mathrm{CONH}_{2}\right) ; 8.23(\mathrm{~s}, 1 \mathrm{H}, H-4)$; $9.16\left(\mathrm{~s}, 1 \mathrm{H}, \mathrm{CONH}_{2}\right) ; 11.25$ (s, 1H, CONH). IR (KBr), cm ${ }^{-1}: v 3305,3238,3110(\mathrm{NH}), 1698,1678$ $(\mathrm{C}=\mathrm{O}), 1650(\mathrm{C}=\mathrm{N})$. A solution of benzoylhydrazonochromene $41 \mathrm{a}(1.54 \mathrm{~g}, 5 \mathrm{mmol})$ in dry and degassed nitrobenzene (10 mL) was refluxed for 10-40 min. During the course of reaction, release of ammonia was observed. After reaction was completed (monitoring by TLC), the mixture was cooled and a precipitate was filtered off and recrystallized from benzene to give $1.13 \mathrm{~g}(78 \%)$ of $1,3,4$ oxadiazolylchromene 45a with m.p. $216-218{ }^{\circ} \mathrm{C}$ (lit. [31] m.p. $224{ }^{\circ} \mathrm{C}$ ). ${ }^{1} \mathrm{H}-\mathrm{NMR}$ (100 MHz, DMSO$\left.d_{6}\right): \delta$ 7.45-8.13 (m, 9H, ArH); 9.02 (s, 1H, H-4). IR (KBr), $\mathrm{cm}^{-1}:$ v $1744(\mathrm{C}=\mathrm{O})$. MS (EI, $\left.70 \mathrm{eV}\right) \mathrm{m} / \mathrm{z}$ (rel.\%): $290\left(\mathrm{M}^{+}, 26\right), 262$ (5), 206 914), 189 (12), 173 (32), 105 (100). Anal. Calcd for $\mathrm{C}_{17} \mathrm{H}_{10} \mathrm{~N}_{2} \mathrm{O}_{3}$ (290.27): C, 70.34; H, 3.47; N, 9.65. Found: C, 70.27; H, 3.62; N, 9.73.

Method B: Benzoylcarbohydrazonamide 12 ( $c f$. Scheme 2) (154 mg, $0.5 \mathrm{mmol})$ was refluxed in a mixture $\mathrm{AcOH} / \mathrm{H}_{2} \mathrm{SO}_{4}(2 \mathrm{~mL})$ for 15-30 min. After the reaction finished, the mixture was cooled and neutralized with aqueous ammonia. The precipitate formed was filtered off, washed with water and cold propan-2-ol $(2 \times 1 \mathrm{~mL})$. The product obtained was recrystallized from an appropriate solvent to afford $112 \mathrm{mg}$ (78\%) of 1,3,4-oxadiazolylchromene 45a. ${ }^{1} \mathrm{H}-\mathrm{NMR}$, IR spectral data, and melting points corroborate identity of the compounds obtained by Methods $A$ and $B$.

6-n-Hexyl-7-hydroxy-2-oxo-3-(5-phenyl-1,3,4-oxadiazol-2-yl)-2H-chromene (45b): 
1,3,4-Oxadiazolylchromene 45b was prepared from carbamoyliminochromene 1c [4b] and benzohydrazide (11) using the reaction conditions described in Method $A$ for the synthesis of 45a. Yield: 68\%. M.p. 241-242 ${ }^{\circ} \mathrm{C} .{ }^{1} \mathrm{H}-\mathrm{NMR}\left(100 \mathrm{MHz}, \mathrm{DMSO}-d_{6}\right): \delta 0.86(\mathrm{t}, 3 \mathrm{H}, J=7.0 \mathrm{~Hz}$, $\left.\mathrm{CH}_{2}\left(\mathrm{CH}_{2}\right)_{4} \mathrm{CH}_{3}\right) ; 1.30\left(\mathrm{~m}, 8 \mathrm{H}, \mathrm{CH}_{2}\left(\mathrm{CH}_{2}\right)_{4} \mathrm{CH}_{3}\right) ; 1.56\left(\mathrm{~m}, 2 \mathrm{H}, \mathrm{CH}_{2}\left(\mathrm{CH}_{2}\right)_{4} \mathrm{CH}_{3}\right) ; 6.82(\mathrm{~s}, 1 \mathrm{H}, H-8) ; 7.64$ (m, 4H, ArH); 8.09 (m, 2H, ArH); 8.85 (s, 1H, H-4); 11.09 (br s, 1H, OH). IR (KBr), cm ${ }^{-1}:$ v 3088 $(\mathrm{OH}), 2851\left(\mathrm{CH}_{\text {alkyl }}\right), 1744(\mathrm{C}=\mathrm{O}), 1618(\mathrm{C}=\mathrm{C}), 1570$. Anal. Calcd for $\mathrm{C}_{23} \mathrm{H}_{22} \mathrm{~N}_{2} \mathrm{O}_{4}(390.43)$ : C, 70.75; H, 5.68; N, 7.17. Found: C, 70.81; H, 5.80; N, 7.22.

\section{References and Notes}

1. Recent reviews on naturally occurred coumarins: (a) Malikov, V. M.; Saidkhodzhaev, A. I. Coumarins. Plants, structure, properties. Khim. Prir. Soedin. 1998, 560-593. (b) Malikov, V. M.; Saidkhodzhaev, A. I. Physical constants and spectral data of coumarins. Part 2. Coumarins: plants, structure, properties. Khim. Prir. Soedin. 1998, 384-432. (c) Malikov, V. M.; Saidkhodzhaev, A. I. Coumarins: plants, structure, properties. Part 1. Coumarin distribution in plants. Khim. Prir. Soedin. 1998, 250-281; [Engl. Transl.: Chem. Nat. Compd. 1998, 34, 202-264]. (d) EstevezBraun, A.; Gonzalez, A. G. Coumarins. Nat. Prod. Rep. 1997, 14, 465-475. (e) Murray, R. D. H. Naturally occurring plant coumarins. Prog. Chem. Org. Nat. Prod. 1997, 72, 1-119.

2. O'Kennedy, R.; Thornes, R. D. Coumarins: biology, applications, and mode of action. John Wiley \& Sons: Chichester; New York, 1997.

3. Zubkov, V. A.; Kovalenko, S. N.; Chernykh, V. P.; Ivkov, S. M. New derivatives of coumarin: 2(N-R-imino)-2H-1-benzopyrans. Khim. Geterotsikl. Soedin. 1994, 760-766; [Engl. Transl.: Chem. Heterocycl. Compd. (N. Y.) 1994, 30, 665-670].

4. (a) Kovalenko, S. N.; Zubkov, V. A.; Chernykh, V. P.; Turov, A. V.; Ivkov, S. M. Recyclization of 2-imino-2H-1-benzopyrans under the influence of nucleophilic reagents. 1 . New approach to the synthesis of 3-(1,3,4-oxadi-, thiadi-, and triazolyl-2)coumarins. Khim. Geterotsikl. Soedin. 1996, 186-192; [Engl. Transl.: Chem. Heterocycl. Compd. (N. Y.) 1996, 32, 163-168]. (b) Kovalenko, S. N.; Chernykh, V. P.; Shkarlat, A. E.; Ukrainets, I. V.; Gridasov, V. I.; Rudnev, S. A. Recyclization of 2-imino-2H-1-benzopyrans under the influence of nucleophilic reagents. 2. Reaction of 2-iminocoumarin-3-carboxamides with o-aminobenzenesulfonamide. Khim. Geterotsikl. Soedin. 1998, 916-920; [Engl. Transl.: Chem. Heterocycl. Compd. (N. Y.) 1998, 34, 791-795]. (c) Bilokin, Y. V.; Kovalenko, S. N.; Bylov, I. E.; Chernykh, V. P. Rearrangements of 2-imino-2H-1-benzopyran-3-carboxamides under action of anthranilic acid as N-nucleophile. Heterocycl. Commun. 1998, 4, 257-260. (d) Kovalenko, S. N.; Vasil'ev, M. V.; Sorokina, I. V.; Chernykh, V. P.; Turov, A. V.; Rudnev, S. A. Recyclization of 2-imino-2H-1-benzopyrans using nucleophilic reagents. 3. Reaction of 2-iminocoumarin-3-carboxamides with o-phenylenediamines and o-amino(thio)phenols. Khim. Geterotsikl. Soedin. 1998, 1664-1667; [Engl. Transl.: Chem. Heterocycl. Compd. (N. Y.) 1998, 34, 1412-1415]. (e) Kovalenko, S. N.; Sytnik, K. M.; 
Nikitchenko, V. M.; Rusanova, S. V.; Chernykh, V. P.; Porokhnyak, A. O. Recyclization of 2imino-2H-1-benzopyrans by the action of nucleophilic reagents. 4. Use of 2-(N-aroylhydrazono) coumarin-3-carboxamides for the synthesis of 3-(1,3,4-oxadiazol-2-yl)coumarins. Khim . Geterotsikl. Soedin. 1999, 190-193; [Engl. Transl.: Chem. Heterocycl. Compd. (N. Y.) 1999, 35 , 167-170]. (f) Vasylyev, M. V.; Bilokin, Y. V.; Branytska, O. V.; Kovalenko, S. M.; Chernykh, V. P. A facile method for synthesis of heterocycles containing tetrahydrobenzo[4,5]thieno[2,3d] pyrimidine and coumarin moieties. Heterocycl. Commun. 1999, 5, 241-242. (g) Bilokin, Y. V.; Vasylyev, M. V.; Branytska, O. V.; Kovalenko, S. M.; Chernykh, V. P. A novel and expedient approach to new heterocycles containing benzothiophene, benzothieno[2,3-d]pyrimidine and coumarin moieties. Tetrahedron 1999, 55, 13757-13766. (h) Sytnik, K. M.; Kovalenko, S. M.; Chernykh, V. P.; Goncharova, V. M. Synthesis and tuberculostatic activities of 2-(Rthiosemicarbazono)coumarin-3-carboxamides. Fiziologichno Aktyvni Rechovyny 1999, (2), 50-53 (in Ukrainian with Engl abstr.). (i) Kovalenko, S. N.; Bylov, I. E.; Belokon, Ya. V.; Chernykh, V. P. Recyclization of 2-imino-2H-1-benzopyrans under the action of nucleophilic reagents. 5. Interaction of 2-imino-2H-1-benzopyran-3-carboxamide with anthranilic acid and its derivatives. Khim. Geterotsikl. Soedin. 2000, 1175-1181.

5. Selim, M. R.; Aly, F. M.; Bedair, A. H.; Abu-Shanab, F. A. Synthesis of some benzoxazin-4-one derivatives and study of their reaction with nucleophilic reagents. J. Indian Chem. Soc. 1992, 69, 688-690.

6. El-Hashash M. A.; Kaddah A. M.; El-Kady M.; Ammer M. M. Some reactions of 3[2'-(4'H,2',1')benzoxazin-4'-only]coumarins and 3(2'-quinazol-4'-onyl)coumarins. Pak. J. Sci. Ind. Res. 1982, 25, 104-108.

7. Enomoto, S.; Sato, K.; Suzuki, G. 3-(4-Oxo-3,4-dihydro-2-quinazolinyl)-7-diethylaminocoumarin dyes. Ger. Offen. 2,005,933 (1970); Chem. Abstr. 1971, 74, 65585.

8. Kametani, T.; Loc, C. V.; Higa, T.; Koizumi, M.; Ihara, M.; Fukumoto, K. Iminoketene cycloaddition. 2. Total synthesis of arborine, glycosminine, and rutecarpine by condensation of iminoketene with amides. J. Am. Chem. Soc. 1977, 99, 2306-2309.

9. Schiemenz, G. P. Zur Reaktion von 2-Hydroxy-benzaldehyd mit Cyanacetamid und Malodinitril. Chem. Ber. 1962, 95, 483-486.

10. Abdel Aziz, M. A.; Daboun, H. A.; Abdel Gawad, S. M. $\alpha$-Cyanothioacetamide and its derivatives in heterocyclic synthesis: preparation of several new 4-oxoquinazoline derivatives. $J$. Prakt. Chem. 1990, 332, 610-618.

11. A similar process on formation of 3-amino-2-cyano-(2-imino-4-methyl-2H-1-benzopyran-3yl)prop-2-enenitrile by a reaction of 2-imino-4-methyl-2H-1-benzopyran-3-carbonitrile with malononitrile, acting as $C$-nucleophile, was reported: O'Callaghan, C. N.; McMurry, T. B. H.; O'Brien, J. E.; Draper, S. M.; Wilcock, D. J. Formation of polyheterocyclic systems by reaction of 2-imino-4-methyl-2H-1-benzopyran-3-carbonitrile with active methylene compounds. J. Chem. Soc., Perkin Trans. 1 1996, 1067-1071. 
12. For a leading list of references on preparation of coumarins and other fused $\alpha$-pyrones from 3-(2hydroxyaryl)propenoic esters through their thermal $E / Z$ isomerization, see: Cartwright, G. A.; $\mathrm{McNab}, \mathrm{H}$. Synthesis of coumarins by flash vacuum pyrolysis of 3-(2-hydroxyaryl)propenoic esters. J. Chem. Res. (S) 1997, 296-297.

13. Brunskill, J. S. A.; De, A.; Elagbar, Z.; Jeffrey, H.; Ewing, D. F. Convenient synthesis of coumarin-3-thiocarboxamides. Synth. Commun. 1978, 8, 533-539.

14. Silin, A. V.; Gorobets, N. Y.; Sytnik, K. M.; Nikitchenko, V. M. Recyclization of substituted 2iminocoumarin-3-carboxamides in aprotic basic solvents. Visn. Khark. Univ. 1997, 395, 274-277; Chem. Abstr. 1998, 129, 290037.

15. O'Callaghan, C. N.; McMurry, T. B. H.; O'Brien, J. E. Isomerisation of benzopyran-2-imines in $\left[{ }^{2} \mathrm{H}_{6}\right]$ dimethyl sulfoxide. J. Chem. Soc., Perkin Trans. 2 1998, 425-429.

16. Hand, E. S.; Jencks, W. P. Mechanism of the reaction of imido esters with amines. J. Am. Chem. Soc. 1962, 84, 3505-3514.

17. Kuhn, R.; Weiser, D. Lactonacetale, eine neue Klasse von Carbonsäure-Derivaten. Angew. Chem. 1957, 69, 371-376.

18. (a) Karasev, A. A.; Lukatskaya, L. L.; Rubtsov, M. I.; Zhikol, E. K.; Yarmolenko, S. N.; Ponomarev, O. A. Synthesis, protolytic equilibrium and stability of 2-amino-3-(2benzimidazolyl)-1-benzopyrylium salts in aqueous alcoholic medium. Zh. Obshch. Khim. 1995, 65, 1547-1557; Chem. Abstr. 1996, 124, 342517. (b) Rubtsov M. I.; Lukatskaya L. L.; Karasev A. A. Structure and reactivity of 2-amino-3-carbamoylchromenylium salts. Zh. Obshch. Khim. 1999, 69, 138-141; [Engl. Transl.: Russ. J. Gen. Chem. 1999, 69, 134-137].

19. Matlack, A. S. Nickel salts of iminoheterocyclic amides. Ger., Offen. 1,806,435 (1969); Chem. Abstr. 1970, 72, P4337.

20. O'Callaghan, C. N. Isomerization of 2-aryl-4-oxo-2,3-dihydrobenzopyrano[2,3-d]pyrimidines to 2-aryl-4-hydroxy-5-H-benzopyrano[2,3-d]pyrimidines. J. Chem. Soc., Perkin Trans. 1 1980, 1335-1337.

21. Review: (a) Coppola, G. M. The chemistry of 4H-3,1-benzoxazin-4-ones. J. Heterocycl. Chem. 1999, 36, 563-588; (b) Abdalla, M. M.; Elkady, M.; El-Farargy, A. F. Synthesis of some 3-(3',1'benzoxazin-4'-one)-6-substituted coumarins and their chemical reactions. Egypt. J. Chem. 1977, 20, 245-257.

22. Ossman, A. E.; El-Zahabi, M. M.; El-Hakim, A. E.; Osman, A. N. Synthesis of 2-cyanomethyl3,1-benzoxazin-4(H)-one. Egypt. J. Chem. 1988, 31, 381-385.

23. Ukrainets, I. V.; Bezugly, P. A.; Treskach, V. I.; Taran, S. G.; Gorokhova, O. V. Ethyl-esters of malonanilic acids - synthesis and pyrolysis. Tetrahedron 1994, 50, 10331-10338.

24. Review: Fry, D. W. Recent advances in tyrosine kinase inhibitors. Annu. Rep. Med. Chem. 1996, 31, 151-160.

25. Czerney, P.; Hartmann, H. Zur Darstellung von 3-Cyancumarinen. J. Prakt. Chem. 1981, 323, 691-693. 
26. O'Callaghan, C. N.; Conalty M. L. Anticancer agents. XIII. Synthesis and antitumor activity of 2iminochromene derivatives. Proc. R. Ir. Acad., Sect. B 1979, 79B, 87-98.

27. Reid, W.; Meyer, A. Über die Verwendung von Cyanacethydrazid zur Darstellung von Stickstoffheterocyclen. I. Eine einfache Synthese von N-amino- $\alpha$-pyridonen. Chem. Ber. 1957, 90, 2841-2848.

28. Nielsen, S. F.; Christensen, S. B.; Cruciani, G.; Kharazmi, A.; Liljefors, T. Antileishmanial chalcones: statistical design, synthesis, and three-dimensional quantitative structure-activity relationship analysis. J. Med. Chem. 1998, 41, 4819-4832.

29. Perrin, D. D.; Armarego, W. L. F. Purification of laboratory chemicals. 3d Eds. Pergamon Press: Oxford, 1988.

30. El-Ahmad, Y.; Brion, J.-D.; Reynaud, P. Synthesis of N-(2-dialkylaminoethyl)-2-oxo-2H-1benzo(thio)pyran-3-carboxamidines. Heterocycles 1993, 36, 1979-1988.

31. Milcent, R. 1,3,4-Oxadiazoles. Synthesis of some polyheterocyclic compounds from (5-phenyl1,3,4-oxadiazol-2-yl)acetic acid. Ann. Chim. (Paris) 1967, 2, 221-226; Chem. Abstr. 1968, 68, 49490.

Samples Availability: Available from the authors.

(C) 2000 by MDPI (http://www.mdpi.org). Reproduction is permitted for noncommercial purposes. 